\title{
IMPACT OF SOME IMPROVED SURFACE IRRIGATION SYSTEM AND NITROGEN FERTILIZATION ON SOME WATER RELATIONS AND PRODUCTIVITY OF MAIZE CROP AT NORTH DELTA \\ Taha, A. A.*; M. M. Ragab ${ }^{* *}$; A, A. A. Mosa* and M.M. A. Shabana** \\ * Soil Science, Fac. Agric. Mansoura University \\ ${ }^{\star *}$ Soils, Water and Environment Res. Inst., Agric. Res. Center Egypt.
}

\begin{abstract}
To evaluate some modern surface irrigation systems and their effects on some water relations and nitrogen use efficiency on maize crop, a field experiment was conducted at El-Hamoul District, Kafr Elshiekh Governorate at North Delta. The experiment included traditional surface irrigation, alternative surface furrow irrigation, gated pipes and alternative gated pipes furrow, with three nitrogen treatments $(0,101$ and $135 \mathrm{Kg} \mathrm{fed}^{-1}$ ).

The main obtained results could be summarized as follows:

- Using gated pipes method for irrigating maize crop resulted in less amount of water applied compared to traditional surface method. On the other hand, gated pipes technique saved irrigation water by 19.5 and $31.4 \%$ for alternative gated pipe technique and gated pipe technique, respectively compared to traditional surface irrigation. This method realized the lowest value of actual water consumptive use ,improved water application efficiency and water distribution efficiency compared to traditional irrigation method

- There is no effect on maize yield due to different irrigation systems used in this study. Whereas, grain yield was increased by $110.9 \%$ and $85.5 \%$ for the $\mathrm{N}$ recommended dose and $75 \%$ of the recommended dose, respectively over control treatment $\left(0 \mathrm{Kg} \mathrm{N} \mathrm{Fed}^{-1}\right)$. It can be observed that alternative furrow irrigation by gated pipe achieved the highest grain and stalk yield followed by gated pipes under the highest nitrogen application rate.

- Nitrogen use efficiency and $\mathrm{N}$ recovery \% was increased with increasing $\mathrm{N}$ level. The highest value of $\mathrm{N}$ recovery \% was found under alternative gated pipe system and the $\mathrm{N}$ recommended dose.

Keywords: Traditional surface irrigation, alternative surface furrow irrigation, gated pipes, alternative gated pipes, nitrogen use efficiency, water relation, maize crop.
\end{abstract}

\section{INTRODUCTION}

Increasing water productivity is the main goal through increasing the water use efficiency. This can be achieved by managing the controlled modern surface irrigation systems and adjusting them to soil hydraulic properties and to the water and nutritional requirements of the specific crop growth.

Increasing the agricultural production per unit volume of water is the main goal through increasing the water use efficiency. This goal can be achieved by advanced surface irrigation through applying gated pipes for 
Taha, A. A. et al.

irrigating field crops. Gated pipe could save irrigation water by $16.94 \%$ for maize compared to traditional surface irrigation (Abo Soliman ,et al. 2002).

Morsi (2001) carried out field experiments to develop furrow surface irrigation by using alternative and surge-alternative systems, in comparison with continuous furrow irrigation, using maize yield as an indicator. The results showed that grain yield for surge alternative method was increased by $3.21 \%$ and $4.73 \%$ comparing with continuous and alternative method, respectively.

Ahmad et al.., (2002) reported that furrow irrigation and nitrogen band placement resulted in the highest grain yield of maize, when they examined the effect of different irrigation methods (flood, furrow and alternate furrow irrigation) and nitrogen application methods (broadcast or band placement)

In their studies on alternate furrow irrigation technique, AbdelMaksoud et al.., (2002) reported that alternate furrow irrigation at 7 days intervals increased maize grain yield by 14.5 and $28.4 \%$, comparable with every-furrow and alternate-furrow irrigation at 14 days intervals, respectively.

Looking at the problems of surface irrigation system, a proximally half of the irrigation water applied was with $24 \%$ going to deep percolation and $24 \%$ to run off (Jensen, 1980). On the other hand, the traditional surface irrigation system can be improved using gated pipes with the furrows or basin irrigation systems without major changes in design or in operating procedure of the current irrigation system. Gated pipes have low cost, relative high application and distribution efficiencies and it easily to be used by the low experienced workers (Abou El-Soud, 2010).

It is well known that nitrogen is the most important element for plant growth and development, and it is an integral component of many compounds essential for plant growth processes including chlorophyll and many enzymes (Mkhabela et al.., 2001).

The main objectives of this work are to evaluate: different surface irrigation systems, amount of water saving, maximizing maize crop yield, water utilization and nitrogen use efficiency under different surface irrigation systems.

\section{MATERIALS AND METHODS}

A field experiment was conducted during the summer season of 2008 in El Hamoul District, Kafr El Shiekh Governorate (4 m altitude, $31^{\circ} 4253^{\circ}$ latitude and $31^{\circ} 0740^{-}$longitude) to evaluate some modern surface irrigation methods and its effect on some water relations and nitrogen use efficiency with maize crop.

The experimental design used was split plot design, the main plots were irrigation treatments which included three types of irrigation systems (I) i.e.

- The traditional furrow irrigation technique $\left(\mathrm{l}_{1}\right)$

- The traditional alternative furrow irrigation system $\left(\mathrm{I}_{2}\right)$

- Gated pipe furrow irrigation system $\left(I_{3}\right)$ 
- Gated pipe alternative irrigation system $\left(\mathrm{I}_{4}\right)$., and

The sub plots were devoted to nitrogen fertilization treatments $(\mathrm{N})$ i.e.,

- $\mathrm{N}_{1}$ - control treatment $\left(0 \mathrm{Kg} \mathrm{N} \mathrm{Fed}^{-1}\right)$

- $\mathrm{N}_{2}-75 \%$ of the recommended dose $\left(101 \mathrm{Kg} \mathrm{N} \mathrm{Fed}^{-1}\right)$

- $\mathrm{N}_{3}$ - The recommended dose $\left(135 \mathrm{Kg} \mathrm{N} \mathrm{Fed}^{-1}\right)$

Maize grains, cultivar triple cross (Sakha 324) were sown in May $11^{\text {th }}$, 2008. Nitrogenous fertilizer in the form of urea $(46.5 \% \mathrm{~N})$ was divided into two equal doses, the first dose was applied before the second irrigation, and the second dose was applied before the next one (the third irrigation).

Potassium fertilizer (recommended dose) was applied as potassium sulphate $\left(48 \% \mathrm{~K}_{2} \mathrm{O}\right)$, before the fourth irrigation. Phoshorus (recommended dose) in the from of Ca-superphosphate $\left(15.5 \% \mathrm{P}_{2} \mathrm{O}_{5}\right)$ was added through soil preparation.

\section{Soil analysis}

- Soil samples were collected from different layers and subjected to the following hydrophysico- chemical analysis according to Richards (1954) and Jackson (1967).

- Moisture parameters; Field capacity (F.C.) and permanent wilting point (P.W.P) were determined by pressure membrane method according to Klute (1986).

Some chemical and physical properties of the experimental soil are shown in tables (1-2).

Table (1): Some chemical properties of the experimental soil before the growing season

\begin{tabular}{|c|c|c|c|c|c|c|c|c|c|c|c|c|c|c|c|}
\hline \multirow{2}{*}{$\begin{array}{l}\text { Soil } \\
\text { depth } \\
\text { (cm) }\end{array}$} & \multirow{2}{*}{$\begin{array}{c}\text { OM } \\
\%\end{array}$} & \multirow[t]{2}{*}{$\mathrm{pH}^{\star}$} & \multirow{2}{*}{$\begin{array}{c}E C^{\star \star} \\
(\mathrm{dS} / \mathrm{m})\end{array}$} & \multicolumn{4}{|c|}{$\begin{array}{l}\text { Soluble cations } \\
\left(\text { meq L}^{-1}\right)\end{array}$} & \multicolumn{4}{|c|}{$\begin{array}{c}\text { Soluble anions } \\
\left(\mathrm{meq} \mathrm{L}^{-1}\right)\end{array}$} & \multirow[t]{2}{*}{ SAR } & \multicolumn{3}{|c|}{$\begin{array}{c}\text { Available } \\
\text { nutrients (ppm) }\end{array}$} \\
\hline & & & & $\mathrm{Na}^{+}$ & $\mathrm{K}^{+}$ & 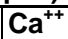 & & & & 7 & & & $\mathbf{N}$ & $\mathbf{P}$ & K \\
\hline $0-15$ & & & & 8 & 0.3 & & & 0 & 5 & 10 & & & 53 & $\overline{91}$ & 201 \\
\hline 1 & 20 & 8.22 & & ) & 0.4 & & & & 4 & & & & ? & 9 & 237 \\
\hline 3 & & 8.26 & & s & 0.7 & 4 & 1 & 0 & 3.5 & 0 & & & 5 & 6 & 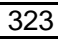 \\
\hline $45-60$ & 56 & 8.29 & 7.17 & 48.8 & 0.7 & 11.5 & 15.8 & 0 & 12.5 & 34.1 & 30.1 & 13.21 & 31.9 & 9.5 & 317 \\
\hline
\end{tabular}

* $\mathrm{pH}$ was determined in soil water suspension (1:2.5).

${ }^{\star *}$ EC was determined in saturated soil paste extract.

Table (2). Some physical properties of the experimental soil before the growing season.

\begin{tabular}{|c|c|c|c|c|c|c|c|c|c|}
\hline \multirow{2}{*}{$\begin{array}{l}\text { Soil depth } \\
\text { (cm) }\end{array}$} & \multicolumn{3}{|c|}{$\begin{array}{l}\text { Particle size } \\
\text { distribution }\end{array}$} & \multirow[b]{2}{*}{ Texture } & \multirow{2}{*}{$\begin{array}{c}\text { Basic } \\
\text { infiltration } \\
\text { rate } \\
(\mathrm{cm} / \mathrm{hr})\end{array}$} & \multirow{2}{*}{$\begin{array}{c}\text { Bulk } \\
\text { density } \\
\left(\mathbf{g} / \mathrm{cm}^{3}\right)\end{array}$} & \multicolumn{3}{|c|}{$\begin{array}{c}\text { Soil moisture } \\
\text { characteristics }\end{array}$} \\
\hline & $\begin{array}{c}\text { Sand } \\
\%\end{array}$ & $\begin{array}{l}\text { Silt } \\
\%\end{array}$ & $\begin{array}{c}\text { Clay } \\
\%\end{array}$ & & & & \begin{tabular}{|c|} 
Field \\
capacity \\
$\%$
\end{tabular} & $\begin{array}{c}\text { Wilting } \\
\text { point } \\
\%\end{array}$ & $\begin{array}{c}\text { Availabl } \\
\text { water } \\
\%\end{array}$ \\
\hline 5 & 16.89 & 23.97 & 59.14 & & \multirow{4}{*}{1.4} & 1.16 & 41.1 & 22.3 & 18.8 \\
\hline 30 & 16.55 & 25.57 & 57.88 & clayey & & 1.8 & 40.1 & 21.8 & 18.3 \\
\hline $30-45$ & 16.22 & 24.52 & 59.26 & clayey & & 1.3 & 38.6 & 20.8 & 17.8 \\
\hline $45-60$ & 17.60 & 26.26 & 56.14 & clayey & & 1.37 & 38.2 & 20.7 & 17.5 \\
\hline
\end{tabular}

\section{- Amount of water applied}

Traditional surface irrigation: the applied irrigation water was measured by using cut -throat flume $(20 \times 90 \mathrm{~cm})$ according to Early (1975). 
Taha, A. A. et al.

Improved surface irrigation (gated pipes): the discharge through an orifice was determined as described by (Brater and King 1976)

- Water consumptive use (CU): was calculated using the equation of Israelson and Hansen (1962).

- Irrigation application efficiency (Ea): Values of irrigation application efficiency (Ea) in percent for each treatment were obtained by dividing the total water stored in the root zone on the applied irrigation water according to Downy (1970) as follows:

$$
\begin{aligned}
& \mathrm{Ea}=\frac{\mathrm{Ws}}{\mathrm{Wd}} \times 100 \quad \text { where: } \\
& \mathrm{Ea}=\text { Water application efficiency }(\%) \\
& \mathrm{Ws}=\text { Water stored in the root zone } \\
& \mathrm{Wd}=\text { Water applied to the field plot. }
\end{aligned}
$$

- Maize yield and yield components: data were recorded for grain yield, plant height, leaf area and chlorophyll (\%). The grain yield was adjusted based on the moisture percent of $15.5 \%$

- Crop water use efficiency (CWUE).

It was calculated by the following equation according to Abd El -Rasool et al.. (1971).

$$
\text { C.W.U.E. }=\frac{\text { Yield }\left(\mathrm{Kg} \mathrm{fed}^{-1}\right)}{\text { Water consumptive use }\left(\mathrm{m}^{3} \mathrm{fed}^{-1}\right)}
$$

- $\quad$ Field water use efficiency (FWUE).

It was calculated in $\mathrm{Kg} \mathrm{m}^{-3}$ for different irrigation systems to clarify how much $\mathrm{Kg}$ yield is produced from one cubic meter applied (Michael,1978)

- Nitrogen in plant: was determined in grain and stalk digestion by microKjeldahl method as explained by Hesse (1971)

- Nitrogen use efficiency was calculated as grain yield $(\mathrm{Kg})$ produced due to adding units of nitrogenous fertilizer .

- $\quad$ Nitrogen recovery \%

Apparent nitrogen recovery of fertilizer (\%) was calculated for each treatment according to the following equation (Crasswell and Godwin , 1984)
Recovery of $\mathrm{N}$ fertilizer \% $=\frac{\begin{array}{c}\mathrm{N} \text {-uptake from fertilized plot }-\mathrm{N} \text {-uptake fron } \\ \text { control }\end{array}}{\mathrm{N}} \mathrm{100}$
$\mathrm{N}$-applied from fertilizer

\section{Statistical analysis}

Data were statistically analyzed using analysis of variance (ANOVA). Treatments means and significance of differences were calculated and presented using (LSD) according to Steel and Torrie (1980) and (LSR) according to Duncan (1955). 


\section{RESULTS AND DISCUSSION}

\section{Some water relations:-}

Amount of irrigation water applied.

Data in Table (3) show that using gated pipes method for irrigating maize crop resulted in less amount of water applied compared to traditional surface method. The lowest amounts of water applied were achieved by $\mathrm{I}_{4}$ (alternative gated pipes system), followed by $I_{3}$ (gated pipes system), where the highest one was obtained from traditional method $l_{1}$. It is worthy to mention that, gated pipes technique saved irrigation water by 19.5 and 31.4 $\%$ for $\mathrm{I}_{4}$ and $\mathrm{I}_{3}$, respectively. These results are in a good agreement with those obtained by Abo Soliman, et al. (2002) and Abou El-Soud (2010).

\section{Actual water consumptive use:-}

Data in Table (3) indicate that the seasonal water consumptive use values for maize crop were affected by surface irrigation methods .The highest value $(54.45 \mathrm{~cm}$.) was obtained from traditional furrow irrigation technique $\left(I_{1}\right)$. While, the lowest one $(39.32 \mathrm{~cm}$.) was obtained under gated pipe system $\left(I_{4}\right)$ followed by gated pipes system $\left(I_{3}\right)$. These results are in somewhat similar to those recorded by Abo Soliman, et al. (2002) and Abou El-Soud (2010).

Water application efficiency:-

Data in Table (3) reveal that the highest value of water application efficiency $(74.11 \%)$ was achieved with gated pipes $\left(I_{3}\right)$ under maize crop, while the lowest one $(66.05 \%)$ was detected under $\left(I_{2}\right)$ treatment. It was expected that application efficiency was improved by $6 \%$ and $8 \%$ due to irrigation with gated pipe $\left(I_{3}\right)$ and alternative gated pipe $\left(I_{4}\right)$ compared to traditional surface irrigation $\left(I_{1}\right)$ and $\left(I_{2}\right)$, respectively. This may be due to uniform water distribution from the outlet of gated pipe compared to traditional surface irrigation which tend to reduce the percolation losses. These results agreed with numerous investigators like Abo Soliman, et al. (2002) and Abou El-Soud (2010).

\section{Water distribution efficiency:-}

Regarding water distribution efficiency, gated pipes system slightly improved the water distribution efficiency compared to traditional irrigation method. The higher value of water distribution efficiency was achieved with irrigation by fresh water for maize crop under gated pipes (Abo Soliman, et al. 2002)

Table (3): Water consumptive use, water stored, irrigation water applied, water saving \%, irrigation application and water distribution efficiency $\%$ as affected by different treatments during maize growing season.

\begin{tabular}{|c|c|c|c|c|c|c|}
\hline $\begin{array}{l}\text { Surface } \\
\text { irrigation } \\
\text { methods }\end{array}$ & $\begin{array}{c}\text { Water } \\
\text { onsumptive } \\
\text { use }(\mathrm{cm})\end{array}$ & $\begin{array}{c}\text { Water } \\
\text { stored }\left(\mathrm{m}^{3}\right. \\
\left.\text { fed }^{-1}\right)\end{array}$ & \begin{tabular}{|c|} 
Irrigation water \\
applied \\
$\left(\mathrm{m}^{3} \mathrm{fed}^{-1}\right)$
\end{tabular} & $\begin{array}{c}\text { Irrigation } \\
\text { application } \\
\text { efficiency } \%\end{array}$ & \begin{tabular}{|c|} 
water \\
saving \\
$\%$
\end{tabular} & $\begin{array}{c}\text { water } \\
\text { distribution } \\
\text { efficiency } \%\end{array}$ \\
\hline$I_{1}$ & 54.45 & 2393.35 & 3422.73 & 69.93 & 0.00 & 95.67 \\
\hline $\mathrm{I}_{2}$ & 44.42 & 1895.64 & 2869.88 & 66.05 & 16.15 & 92.75 \\
\hline$I_{3}$ & 46.36 & 2041.45 & 2754.74 & 74.11 & 19.52 & 96.04 \\
\hline $\mathrm{I}_{4}$ & 39.32 & 1689.86 & 2349.77 & 71.92 & 31.35 & 93.29 \\
\hline
\end{tabular}


Taha, A. A. et al.

\section{Water use efficiency of maize:}

Data in Table (4) showed a highly significant effect of irrigation systems on water use efficiency (CWUE and FWUE). The obtained results reveal that the highest value of FWUE $\left(2.01 \mathrm{~kg}_{\text {grain }} \mathrm{m}^{-3}\right)$ was obtained under $\left(\mathrm{I}_{4}\right)$ and recommended dose of nitrogen $\left(\mathrm{N}_{3}\right)$. Meanwhile, the lowest value of FWUE $\left(1.25 \mathrm{~kg}\right.$ grain $\left./ \mathrm{m}^{3}\right)$ was achieved by the control $\left(\mathrm{I}_{1}\right)$ under $\left(\mathrm{N}_{3}\right)$.

On the other hand, crop water use efficiency for maize grain (CWUE) is significantly affected by irrigation systems and nitrogen dose. It could be observed from the data that the highest value of CWUE $\left(2.7 \mathrm{~kg}\right.$ grain $\left./ \mathrm{m}^{3}\right)$ was achieved under $\left(\mathrm{I}_{4}\right)$ and $\left(\mathrm{N}_{3}\right)$, while the lowest one $\left(1.84 \mathrm{~kg} \mathrm{grain} / \mathrm{m}^{3}\right)$ was recorded with control $\left(\mathrm{I}_{1}\right)$. It can be observed that the values of CWUE and FWUE gradually increased with increasing nitrogen dose up to $135 \mathrm{Kg} \mathrm{fed}^{-1}$ $\left(\mathrm{N}_{3}\right)$.

By other words, using modern irrigation by gated pipes improved FWUE and CWUE values. This may be attributed to the amounts of the water applied and consumed as well as the crop productivity. These results are in somewhat similar to those recorded by Abo Soliman ,et al. (2002), Sonbol,et al. (2009) and Abou El-Soud (2010).

Table (4): Maize grain yield, crop (CWUE) and field (FWUE) water use efficiencies as affected by irrigation system and nitrogen fertilizer.

\begin{tabular}{|c|c|c|c|c|}
\hline $\begin{array}{c}\text { Surface irrigation } \\
\text { methods }\end{array}$ & $\begin{array}{c}\text { Nitrogen } \\
\text { fertilization }\end{array}$ & $\begin{array}{c}\text { Grain yield } \\
\left(\mathrm{kg} \mathrm{fed}^{-1}\right)\end{array}$ & $\begin{array}{c}\text { CWUE (kg } \\
\left.\mathrm{m}^{-3}\right)\end{array}$ & $\begin{array}{c}\text { FWUE } \\
\left(\mathrm{kg} \mathrm{m}^{-3}\right)\end{array}$ \\
\hline \multirow{3}{*}{$I_{1}$} & $\mathrm{~N} 1$ & 2560.93 & $1.21^{\mathrm{J}}$ & $0.77^{\mathrm{J}}$ \\
\hline & $\mathrm{N} 2$ & 4232.03 & $1.81^{\mathrm{h}}$ & $1.24^{\mathrm{h}}$ \\
\hline & N 3 & 4428.03 & $1.84^{\mathrm{g}}$ & $1.25^{\mathrm{g}}$ \\
\hline \multirow{3}{*}{$\mathrm{I}_{2}$} & $\mathrm{~N} 1$ & 2736.9 & $1.56^{\prime}$ & $0.99^{\prime}$ \\
\hline & N2 & 3709.01 & $2.04^{\mathrm{e}}$ & $1.29^{\dagger}$ \\
\hline & N 3 & 4548.89 & $2.25^{d}$ & $1.53^{\mathrm{d}}$ \\
\hline \multirow{3}{*}{$\mathrm{I}_{3}$} & $\mathrm{~N} 1$ & 1883.26 & $1.04^{\prime}$ & $0.71^{\prime}$ \\
\hline & $\mathrm{N} 2$ & 3936.28 & $2.00^{\top}$ & $1.43^{\mathrm{e}}$ \\
\hline & N 3 & 4699.57 & $2.28^{c}$ & $1.65^{\mathrm{C}}$ \\
\hline \multirow{3}{*}{$\mathrm{I}_{4}$} & $\mathrm{~N} 1$ & 1623.12 & $1.01^{k}$ & $0.71^{k}$ \\
\hline & $\mathrm{N} 2$ & 4458.12 & $2.68^{\mathrm{b}}$ & $1.90^{\mathrm{b}}$ \\
\hline & N3 & 4891.43 & $2.71^{\mathrm{a}}$ & $2.01^{a}$ \\
\hline \multicolumn{2}{|c|}{ F Test } & ** & *** & 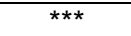 \\
\hline \multicolumn{2}{|c|}{ LSD at 0.05} & 521.62 & 2.42 & 2.07 \\
\hline
\end{tabular}

YIELD

Irrigation effect:

Data in Table (5) reveal insignificant effect on grain and stalk of maize yield due to irrigation treatments. Using gated pipe technique all furrows recorded the highest reduction in grain yield but not insignificant ($6.25 \%)$ as compared to control treatment $\left(I_{1}\right)$ 


\section{Nitrogen fertilization effect}

As shown in Table (5) data reveal that increasing nitrogen application rates increased grain and stalk yield of maize. High significant effect is detected on maize yield due to nitrogen fertilization, where the highest grain yield $\left(4642 \mathrm{Kg} \mathrm{Fed}^{-1}\right)$ was obtained with the highest nitrogen application dose $\left(\mathrm{N}_{3}\right)$.

Grain yield increased by $110.9 \%$ and $85.5 \%$ for $\mathrm{N}_{3}$ and $\mathrm{N}_{2}$ compared to $\mathrm{N}_{1}$ treatment, respectively. Data also reveal that stalk yield took the same trend of grain yield, where the mean values of stalk yield increased by 52.3 and $71.3 \%$ for $N_{2}$ and $N_{3}$ compared to $N_{1}$, respectively.

It is well known that nitrogen is the most important element for plant growth and development, and it is an integral component of many compounds essential for plant growth processes including chlorophyll and many enzymes (Mkhabela et al.., 2001).

These results agree with numerous investigators like Mosa (2006).

Table (5): Effect of irrigation and nitrogen fertilization on grain and stalk yield $\left(\mathrm{Kg} \mathrm{fed}^{-1}\right)$ of maize crop.

\begin{tabular}{|c|c|c|c|c|}
\hline Treatments & $\begin{array}{c}\text { Grain } \\
\left(\mathrm{Kg} \mathrm{fed}^{-1}\right)\end{array}$ & $\begin{array}{c}\text { Relative } \\
\text { change \% }\end{array}$ & $\begin{array}{c}\text { Stalk } \\
\left(\mathrm{Kg} \mathrm{fed}^{-1}\right)\end{array}$ & $\begin{array}{c}\text { Relative } \\
\text { change \% }\end{array}$ \\
\hline \multicolumn{5}{|c|}{ Irrigation Treatment } \\
\hline$I_{1}$ & 3740.3 & 0 & 12683.3 & 0 \\
\hline $\mathrm{I}_{2}$ & 3665.0 & -2.01 & 12916.6 & 1.83 \\
\hline$I_{3}$ & 3506.4 & -6.25 & 12283.3 & -3.15 \\
\hline $\mathrm{I}_{4}$ & 3657.6 & -2.21 & 12216.7 & -3.68 \\
\hline F-Test & ns & - & ns & - \\
\hline LSD at 0.05 & 441.60 & - & 1524.9 & - \\
\hline \multicolumn{5}{|c|}{ Nitrogen fertilization effect } \\
\hline N1 & $2201.1^{c}$ & 0 & $8887.5^{\mathrm{C}}$ & 0 \\
\hline N2 & $4083.9^{b}$ & 85.5 & $13537.5^{b}$ & 52.32 \\
\hline N3 & $4642.0^{a}$ & 110.9 & $15225^{\mathrm{a}}$ & 71.30 \\
\hline F-Test & $\star * * *$ & - & $* * *$ & - \\
\hline LSD at 0.05 & 260.81 & - & 746.5 & - \\
\hline
\end{tabular}

* In the same column, means followed by a common letter are not significantly different at $5 \%$ level by Duncan (1955).

\section{Interaction effect:}

The influence of interaction between irrigation treatments and nitrogen fertilization on grain yield was significant for grain yield but insignificant for stalk yield. As shown in Table (6), it can be observed that $\left(I_{4}\right)$ achieved the highest grain and stalk yield followed by $\left(I_{3}\right)$ under the highest nitrogen application level. This may be due to the improvement of soil aeration conditions and more uniformity of water distribution along the furrow, (Morsi 2001), enhancing root system (primary root number, root density and total root dry weight), (Kang et al.., 2000) and enhancing water and nutrients uptake (Abdel-Maksoud et al.., 2002). 
Taha, A. A. et al.

Table (6): The interactions effect between irrigation system and nitrogen fertilization treatments on maize grain and stalk yields (Kg Fed $^{-1}$ ).

\begin{tabular}{|c|c|c|c|}
\hline \multicolumn{2}{|c|}{ Season } & \multicolumn{2}{c|}{ First season } \\
\hline \multicolumn{2}{|c|}{ Treatments } & Grain & Stalk \\
\hline \multirow{3}{*}{$I_{1}$} & $\mathrm{~N} 1$ & $2560.93^{\mathrm{e}}$ & $9500^{\mathrm{d}}$ \\
\cline { 2 - 4 } & $\mathrm{N} 2$ & $4232.03^{\mathrm{bcd}}$ & $13650^{\mathrm{bc}}$ \\
\cline { 2 - 4 } & $\mathrm{N} 3$ & $4428.03^{\mathrm{abc}}$ & $14900^{\mathrm{ab}}$ \\
\hline \multirow{3}{*}{$\mathrm{I}_{2}$} & $\mathrm{~N} 1$ & $2736.9^{\mathrm{e}}$ & $9800^{\mathrm{d}}$ \\
\cline { 2 - 4 } & $\mathrm{N} 2$ & $3709.01^{\mathrm{a}}$ & $13650^{\mathrm{bc}}$ \\
\cline { 2 - 4 } & $\mathrm{N} 3$ & $4548.89^{\mathrm{ab}}$ & $15300^{\mathrm{ab}}$ \\
\hline \multirow{3}{*}{$\mathrm{I}_{3}$} & $\mathrm{~N} 1$ & $1883.26^{\dagger}$ & $7700^{\mathrm{e}}$ \\
\cline { 2 - 4 } & $\mathrm{N} 2$ & $3936.28^{\mathrm{cd}}$ & $13850^{\mathrm{abc}}$ \\
\cline { 2 - 4 } & $\mathrm{N} 3$ & $4699.57^{\mathrm{ab}}$ & $15300^{\mathrm{ab}}$ \\
\hline \multirow{3}{*}{$\mathrm{I}_{4}$} & $\mathrm{~N} 1$ & $1623.12^{\dagger}$ & $8250 \mathrm{~d}^{\mathrm{e}}$ \\
\cline { 2 - 4 } & $\mathrm{N} 2$ & $4458.12^{\mathrm{abc}}$ & $13000^{\mathrm{c}}$ \\
\cline { 2 - 4 } & $\mathrm{N} 3$ & $4891.43^{\mathrm{a}}$ & $15400^{\mathrm{a}}$ \\
\hline \multicolumn{2}{|c|}{$\mathrm{F}$ Test } & ${ }^{\mathrm{a}}$ & $\mathrm{ns}$ \\
\hline \multicolumn{2}{|c|}{ LSD at 0.05} & 521.62 & 1493.05 \\
\hline
\end{tabular}

\section{PLANT GROWTH MEASUREMENTS:}

\section{Plant height:}

Data presented in Table (7) exhibit a significant influence of irrigation systems on maize plant height. The highest mean value of plant height is achieved with $\left(I_{1}\right)$ followed by $\left(I_{4}\right)$. While the lowest ones are recorded by $I_{3}$ and $\mathrm{I}_{2}$. the longest plants are recorded with gated pipes system (Abou ElSoud, 2010)

Regarding to nitrogen effect, data indicate that plant height values are significantly affected by nitrogen application rates up to $135 \mathrm{Kg} \mathrm{N}^{-1}$.

The interaction effect between irrigation techniques and nitrogen fertilization rates is significant. The highest value is achieved by the combination between $\left(\mathrm{I}_{4}\right)$ and $\mathrm{N}_{3}$. These results are in harmony with those obtained by Sahar (2005) and Sonbol,et al. (2009)

\section{Leaf area:}

The effect of different irrigation systems and nitrogen fertilization on of maize crop is presented in Table (7). Data impose a significant effect on leaf area due to irrigation systems. The highest mean value was obtained under $\left(I_{4}\right)$ followed by $\left(I_{2}\right)$, while the lowest one was recorded with $\left(I_{3}\right)$.Also, nitrogen show high significant effect on leaf area which increased with increasing $\mathrm{N}$ level up to the recommended dose. The tendency of these results are similar to those obtained by Sahar (2005) and Sonbol, et al. (2009)

Concerning the interaction effect between irrigation systems and nitrogen fertilization, data in Table (8) show insignificant interaction effect on leaf area. 


\section{Chlorophyll:}

Data in Table (7) indicate that maize chlorophyll contents are insignificantly increased under different irrigation systems while, nitrogen fertilizer rates impose highly significant effects on chlorophyll content The highest mean values of chlorophyll $(59.11 \%)$ is recorded with the highest rate of nitrogen fertilizer. while, the lowest one is found with the control. Because the relationship between leaf chlorophyll content and $\mathrm{N}$ concentration is not universal for all crops or across cultivars, it is difficult to calibrate chlorophyll meters directly in terms of $\mathrm{N}$ concentration. The interaction between irrigation systems and nitrogen fertilization on chlorophyll content is not significant. These results are similar to those obtained by Sahar (2005)

Table (7): Effect of irrigation and nitrogen fertilization on maize plant height, leaf area and chlorophyll content.

\begin{tabular}{|c|c|c|c|}
\hline Treatments & $\begin{array}{l}\text { Plant height } \\
\text { (cm) }\end{array}$ & $\begin{array}{l}\text { Leaf area } \\
\left(\mathrm{cm}^{2}\right)\end{array}$ & Chlorophyll \% \\
\hline \multicolumn{4}{|c|}{ Irrigation Treatment } \\
\hline 11 & $313^{\mathrm{a}}$ & $812.55^{\mathrm{bc}}$ & $51.53^{\mathrm{ab}}$ \\
\hline 12 & $268.55^{b}$ & $833.66^{\mathrm{ab}}$ & $54.32^{a}$ \\
\hline 13 & $263^{b}$ & $766.64^{\mathrm{c}}$ & $46.52^{\mathrm{b}}$ \\
\hline 14 & $303.88^{\mathrm{a}}$ & $869.57^{\mathrm{a}}$ & $51.18^{\mathrm{ab}}$ \\
\hline F-Test & ** & * & ns \\
\hline LSD at 0.05 & 23.08 & 47.74 & 5.18 \\
\hline \multicolumn{4}{|c|}{ Nitrogen fertilization effect } \\
\hline $\mathrm{N} 1$ & $251.75^{\mathrm{C}}$ & $685.77^{\mathrm{C}}$ & $39.75^{\mathrm{C}}$ \\
\hline N2 & $297.41^{b}$ & $825.39^{b}$ & $53.81^{b}$ \\
\hline N3 & $312.16^{\mathrm{a}}$ & $950.66^{\mathrm{a}}$ & $59.11^{\mathrm{a}}$ \\
\hline F-Test & $\star \star \star *$ & $\star * \star$ & $\star \star * \star$ \\
\hline LSD at 0.05 & 7.54 & 50.77 & 3.72 \\
\hline
\end{tabular}

Table (8): The interaction effect between irrigation and nitrogen fertilization treatments on maize plant height, leaf area and chlorophyll content.

\begin{tabular}{|c|c|c|c|c|}
\hline \multicolumn{2}{|c|}{ Treatments } & Plant height $(\mathrm{cm})$ & Leaf area $\left(\mathrm{cm}^{2}\right)$ & Chlorophyll\% \\
\hline \multirow{3}{*}{11} & $\mathrm{~N} 1$ & $288.66^{\mathrm{bc}}$ & $690.33^{\mathrm{ef}}$ & $40.14^{\mathrm{C}}$ \\
\hline & $\mathrm{N} 2$ & $326.33^{a}$ & $811.13^{\mathrm{bcd}}$ & $54.39^{a b}$ \\
\hline & N3 & $324^{a}$ & $936.2 a$ & $60.08^{\mathrm{a}}$ \\
\hline \multirow{3}{*}{12} & $\mathrm{~N} 1$ & $241^{\mathrm{e}}$ & $713.73^{\mathrm{de}}$ & $44.34^{\mathrm{C}}$ \\
\hline & $\mathrm{N} 2$ & $263^{d}$ & $790.1^{\text {cde }}$ & $58.4^{\mathrm{a}}$ \\
\hline & N3 & $301.66^{b}$ & $997.16^{a}$ & $60.24^{a}$ \\
\hline \multirow{3}{*}{13} & N1 & $215^{\dagger}$ & $606.29^{\dagger}$ & $36.89^{C}$ \\
\hline & $\mathrm{N} 2$ & $283^{c}$ & $797.09^{\text {bcde }}$ & $46.34^{\mathrm{bc}}$ \\
\hline & N3 & $291^{\mathrm{DC}}$ & $896.55^{\mathrm{abc}}$ & $56.35^{\text {ab }}$ \\
\hline \multirow{3}{*}{14} & N1 & $262.33^{d}$ & $732.73^{\mathrm{de}}$ & $37.64^{\mathrm{C}}$ \\
\hline & $\mathrm{N} 2$ & $317.33^{\mathrm{a}}$ & $903.26^{\text {ab }}$ & $56.14^{\text {ab }}$ \\
\hline & N3 & $332^{a}$ & $972.73^{a}$ & $59.77^{a}$ \\
\hline \multicolumn{2}{|c|}{ F Test } & ** & ns & ns \\
\hline \multicolumn{2}{|c|}{ LSD at 0.05} & 15.08 & 101.54 & 7.44 \\
\hline
\end{tabular}


Taha, A. A. et al.

Effect of irrigation systems, nitrogen fertilizer and their interactions on nitrogen concentration and uptake by maize crop.

Irrigation effect:

Data in Table (9) illustrate the impact of irrigation treatments on nitrogen concentration and its uptake by maize organs, and it can observe that nitrogen concentration is increased in alternate furrow irrigation treatments $\left(I_{2}\right.$ and $\left.I_{4}\right)$ comparing with traditional irrigation treatment $\left(I_{1}\right)$.in addition to the nitrogen concentration increased under gated pipe $\left(I_{3}\right.$ and $\left.I_{4}\right)$ comparing with traditional irrigation treatment $\left(\mathrm{I}_{1}\right)$.

This result may be explained as the alternate furrow irrigation enhanced root volume as a result of good aeration and improving soil physical properties (Kang et al.., 2000) \& (Morsi 2001), then improving root volume which increased nitrogen uptake. Similar results were also obtained by (Aiad 2003 and Mosa 2006).

Further more, decreasing nitrate leaching as it will be explained in the interaction between irrigation and nitrogen fertilization .

The highest mean values of nitrogen concentration in maize grains and stalks are detected with $\mathrm{I}_{4}$ followed by $\mathrm{I}_{3}$.

Nitrogen uptake takes the same behavior of nitrogen concentration, as nitrogen uptake is highly significant increased with decreasing irrigated furrows.

There is no doubt that nutrient concentration in stalk tissues is reflects its concentration in grains, so it can predict that irrigation treatment highly significant affected nitrogen concentration in stalk.

Table (9): Effect of irrigation systems and nitrogen fertilization treatments on nitrogen concentration and uptake by maize crop .

\begin{tabular}{|c|c|c|c|c|}
\hline \multirow{2}{*}{ Treatments } & \multicolumn{2}{|c|}{ Nitrogen concentration (\%) } & \multicolumn{2}{|c|}{ Nitrogen uptake (kg fed-1) } \\
\hline & Grain & Stalk & Grain & Stalk \\
\hline \multicolumn{5}{|c|}{ Irrigation Treatment } \\
\hline 11 & $0.83^{\mathrm{d}}$ & $0.58^{\mathrm{d}}$ & $27.24^{b}$ & $18^{\mathrm{b}}$ \\
\hline 12 & $0.89^{c}$ & $0.6^{\mathrm{C}}$ & $28.8^{b}$ & $18.2^{\mathrm{D}}$ \\
\hline 13 & $0.94^{b}$ & $0.64^{b}$ & $29.68^{b}$ & $19.1^{b}$ \\
\hline 14 & $1.09^{a}$ & $0.77^{a}$ & $35.83^{a}$ & $21.7^{a}$ \\
\hline F-Test & 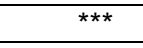 & 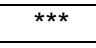 & $\star \star *$ & ** \\
\hline LSD at 0.05 & 7.95 & 1.57 & 3.67 & 1.52 \\
\hline \multicolumn{5}{|c|}{ Nitrogen fertilization effect } \\
\hline N1 & $0.73^{\mathrm{C}}$ & $0.45^{\mathrm{C}}$ & $13.54^{\mathrm{C}}$ & $8.9^{C}$ \\
\hline N2 & $0.87^{b}$ & $0.68^{b}$ & $30.05^{b}$ & $21.11^{\mathrm{b}}$ \\
\hline N3 & $1.21^{\mathrm{a}}$ & $0.81^{a}$ & $47.58^{\mathrm{a}}$ & $27.69^{\mathrm{a}}$ \\
\hline F-Test & $\star \star \star$ & $\star \star \star$ & $\star \star \star *$ & $\star \star \star *$ \\
\hline LSD at 0.05 & 3.78 & 4.35 & 2.19 & 1.08 \\
\hline
\end{tabular}

Nitrogen fertilization effect:

Data obtained in Table (9) show that nitrogen concentration (\%) and its uptake $\left(\mathrm{Kg} \mathrm{Fed}^{-1}\right)$ of both grain and stalk organs increased with increasing nitrogen levels as a result of increasing amounts of available nitrogen in the root zone. 
The statistical analysis revealed that nitrogen concentration and uptake increased significantly in grain and stalk with increasing nitrogen application rate from 0 to $135 \mathrm{Kg} \mathrm{N} \mathrm{Fed}^{-1}$. The highest amounts of nitrogen uptake of grains and stalks, 47.6 and $27.7 \mathrm{Kg} \mathrm{N} \mathrm{Fed}^{-1}$, respectively were found under $\left(\mathrm{N}_{3}\right)$ whereas, the lowest ones for straw are detected under control treatment (13.5 and $8.9 \mathrm{Kg} \mathrm{N} \mathrm{Fed}^{-1}$ respectively). These results are in accordance with findings of Sahar (2005) and Mosa, (2006).

Interactions effect:

Data in Table (10) reveal the interaction effect between irrigation systems and nitrogen fertilization on nitrogen concentration and its uptake by grain and stalk.

Concerning nitrogen concentration and uptake, it is obvious that the effect of interactions between irrigation and nitrogen fertilization are highly significant with grains and stalk. Regarding to data of nitrogen concentration in grain and stalk, it can be observed that $\mathrm{I}_{4}$ treatment was the superior irrigation treatment with all nitrogen levels, and this is attributed to less nitrate leaching, and so increasing nitrogen concentration in root zone.

Mosa, (2006).

Similar results were obtained by Abde-Maksoud et al., (2002) and

Table (10): Interaction effect between irrigation and nitrogen fertilization treatments on nitrogen concentration (\%) and nitrogen uptake $\left(\mathrm{kg} \mathrm{fed}^{-1}\right)$ of grains and stalk

\begin{tabular}{|c|c|c|c|c|c|}
\hline \multirow{2}{*}{\multicolumn{2}{|c|}{ Treatments }} & \multirow{2}{*}{\multicolumn{2}{|c|}{$\begin{array}{c}\text { Nitrogen concentration } \\
(\%)\end{array}$}} & \multicolumn{2}{|c|}{$\begin{array}{l}\text { Nitrogen uptake } \\
\left(\mathbf{k g ~ f e d}^{-1}\right)\end{array}$} \\
\hline & & Grain & & Grain & Stalk \\
\hline \multirow{3}{*}{ I1 } & N1 & $0.657^{\prime}$ & $0.32^{\prime}$ & $14.2 f^{9}$ & $6.86^{9}$ \\
\hline & $\mathrm{N} 2$ & $0.789^{9}$ & $0.63^{1}$ & $28.16^{\mathrm{e}}$ & $19.7^{\mathrm{e}}$ \\
\hline & N3 & $1.052^{\mathrm{d}}$ & $0.81^{b}$ & $39.3^{c}$ & $27.46^{6}$ \\
\hline \multirow{3}{*}{12} & N1 & $0.723^{n}$ & $0.46^{J}$ & $16.7^{\dagger}$ & $10.2^{\mathrm{f}}$ \\
\hline & N2 & $0.854^{\dagger}$ & $0.6^{9}$ & $26.76^{\mathrm{e}}$ & $18.6^{\mathrm{e}}$ \\
\hline & N3 & $1.117^{\mathrm{C}}$ & $0.74^{\mathrm{d}}$ & $42.9^{\mathrm{bc}}$ & $25.7^{\mathrm{bc}}$ \\
\hline \multirow{3}{*}{13} & N1 & $0.723^{n}$ & $0.46^{j}$ & $11.5^{\mathrm{g}}$ & $8.03^{9}$ \\
\hline & N2 & $0.92^{\mathrm{e}}$ & $0.7^{\mathrm{e}}$ & $30.6^{\text {de }}$ & $22.2^{d}$ \\
\hline & N3 & $1.183^{b}$ & $0.77^{\mathrm{C}}$ & $46.9^{b}$ & $27^{b}$ \\
\hline \multirow{3}{*}{14} & $\mathrm{~N} 1$ & $0.854^{\prime}$ & $0.56^{n}$ & $11.7^{\mathrm{g}}$ & $10.6^{\prime}$ \\
\hline & $\mathrm{N} 2$ & $0.92^{\mathrm{e}}$ & $0.81^{b}$ & $34.66^{d}$ & $23.96^{\mathrm{cd}}$ \\
\hline & N3 & $1.512^{\mathrm{a}}$ & $0.95^{\mathrm{a}}$ & $61.1^{a}$ & $30.6^{a}$ \\
\hline \multicolumn{2}{|c|}{$\frac{1}{\mathrm{~F} \text { Test }}$} & $* * *$ & $z^{* \star *}$ & $* \star *$ & $* *$ \\
\hline \multicolumn{2}{|c|}{ LSD at 0.05} & 7.56 & 8.71 & 4.38 & 2.17 \\
\hline
\end{tabular}

\section{Nitrogen use efficiency (NUE):}

It is defined as the amount of harvested crop that is produced per unit of nitrogen supplied during the growing season. The effects of irrigation technique on nitrogen use efficiency are shown in Fig (1). It is well known that increasing nitrogen units applied led to an increase in yield according to Mitscerlich theory, so we can observe that nitrogen use efficiency attributed by $\mathrm{N}_{2}$ is higher than that obtained by $\mathrm{N}_{3}$, with all irrigation treatments. 
Taha, A. A. et al.

Data clearly show that the highest values of NUE are obtained by $\mathrm{I}_{4}$ irrigation treatment, followed by $I_{1}$ and the lowest one is detected under $I_{2}$ irrigation treatment.

These results are in accordance with those obtained by AbdelMaksoud et al., (2002), Sahar (2005) and Mosa, (2006).

\section{Nitrogen -recovery:}

Fig (1) shows the total nitrogen recovery in the whole maize plant (grains \& straw) at maturity stage. Data indicate that nitrogen recovery was increased with increasing $\mathrm{N}$ level. The highest value of $\mathrm{N}$ recovery $\%$ was found under $I_{4}$ and $N_{3}$ whereas, the lowest one was found under $I_{2}$ and $N_{3}$. Similar results were obtained by Sahar (2005)

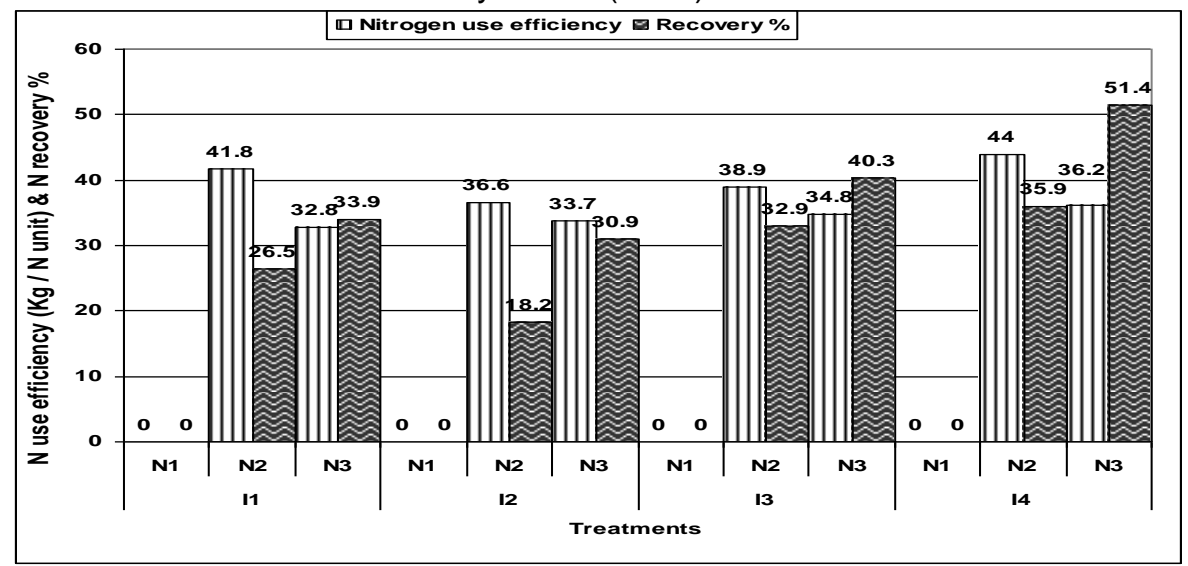

Fig. (1). Effect of irrigation treatments on nitrogen use efficiency and $N$ recovery for maize crop .

\section{Conclusion}

Using alternative gated pipe system for irrigating maize crop in combination with application of nitrogen recommended dose led to improving water and nitrogen efficiencies, and saving more water without observed reduction in maize crop yield

\section{REFERENCES}

Abd El-Rasool, S.F.; H.W. Tawadros; W.I. Miseha and F.N.Mahrous (1971). Effect of irrigation and fertilization on water use efficiency by wheat. Fertilization Conf. Ain Shams Univ., Cairo, Egypt

Abdel-Maksoud, H. H. ; S. A. Othman and A. Y. El-Tawil (2002). Improving water and $\mathrm{N}$-use utilization via alternate-furrow irrigation technique. J. Agric. Sci. Mansoura Univ., 27(12):8761-8769.

Abo Soliman, M. S. M. ; M. M. Saied ; S. M. El - Barbary and M. M. Ragab (2002). Improvd irrigation technique under reuse of water in North delta, Int.symp.on Optimum Resources Utilization in Salt-Affected Ecosystems in Arid and Semi-Arid Regions, Cairo.8-11 Apr., 2002: 161-169. 
Abou El-Soud ,H. M (2010). Studies on water and salt movement under surface and drip irrigation systems in Nile delta soils. M.Sc. Thesis, Mansoura Univ. Fac. of Agric. Egypt.

Ahmad, R. ; A. Mahmood ; M. Ikraam and B. Hassan (2002). Influence of different irrigation methods and band placement of nitrogen on maize productivity. Inter. J. Agric. and Biology. 4(4):540-543

Aiad, M. A. M. (2003). Effect of surge irrigation on water consumptive use and nutrient uptake of cotton. M.Sc. Thesis, Mansoura Univ. Fac. of Agric. Egypt.

Brater, E.F. and H.W. King.(1976). Handbook of Hydraulics, McGeavv. Hill Book company. 6l" Ed. NY.

Crasswell. E. T. and D. C. Godwin. (1984). The efficiency of nitrogen fertilizers applied to cereals in different climates. Adv. Plant Nutrition 1: $1-55$.

Downy, LA. (1970). Water use by maize at three plant densities. Paper, 33, FAO, Rome.

Duncan, D. B. (1955). Multiple range and multiple F-test. Biometrics, 11:1-42

Early, A.C. (1975). Irrigation Scheduling for wheat in Punjab, Cento Sci. Prog. Optimum use of water in Agric. RPT. 17, Lyallpur, Pakistan, 3-5 March, pp, 115-127.

Hesse, P. R. (1971)." A Text Book of Soil Chemical Analysis". Juan Murry (Publisher) Ltd, London.

Israelson, O.W. and V.E. Hansen (1962). "Irrigation Principles and Practices". 3 rd Ed.. John Willey \& Sons. New York.

Jackson, M.L. (1967). Soil Chemical Analysis. Prentice-Hall of India, New Delhi

Jensen , M.E.(1980). Design and operation of farm irrigation systems .International Standard Book No. 0-916150-28.3. The American Society of Agric.Eng.2950 ,Niles Road, St.Joseph , Michigan 49085 ,USA P 663-716.

Kang, S.; Z. Liang ; Y. Pan ; P. Shi and J. Zhang (2000). Alternate furrow irrigation for maize production in an arid area. Agric. Water Manag. 45(3):267-274

Klute, A. (1986) . Methods of Soil Analysis (part 1). Amer. Soc. Agron., Inc. Madison, Wisconsin, USA. 3rd edition.

Michael, A.M. (1978). Irrigation Theory and Practice. Vikas Publishing House, New Delhi, 1978.

Mkhabela M. S. ; M. S. Mkhabela and J. Pali-Shikhulu (2001). Response of maize (Zea mays L.) cultivars to different levels of nitrogen application in Swaziland. Seventh Eastern and Southern Africa Regional Maize Conf. pp.377-381.

Morsi T. M. (2001). A study on irrigation systems developing of furrow irrigation methods for corn crop under local conditions, M.Sc. Thesis, Fac. Agric., Tanta Univ., Egypt

Mosa, A. A. (2006). Water use efficiency and nutrients uptake as affected by alternate furrow irrigation technique and fertilization of maize. Ph.D. Thesis, Mansoura Univ. Fac. Agric. Egypt. 
Taha, A. A. et al.

Richards, L. A. (1954). "Diagnosis and Improving of Saline and Alkaline Soils". U. S., Salinity Laboratory Staff. Agric. Handbook, No.60.

Sahar, H. R. (2005). Effect of bio and organic fertilization on Zea mays. M.Sc. Thesis, Mansoura Univ. Fac. of Agric. Egypt.

Sonbol,H.A.; E.M. El-Hadidi ; M.M. Saied and H.M Abou El-Soud (2009).Comparison of some surface and drip irrigation systems on maize crop. J. Agric. Mansoura Univ., 34(6):7199-7210.

Steel, R. G. D. and J. H. Torrie (1980). "Principles and Procedure of Statistics". A Biometrics Approach 2nd . Mc-Grow Hill Book Company, New York.

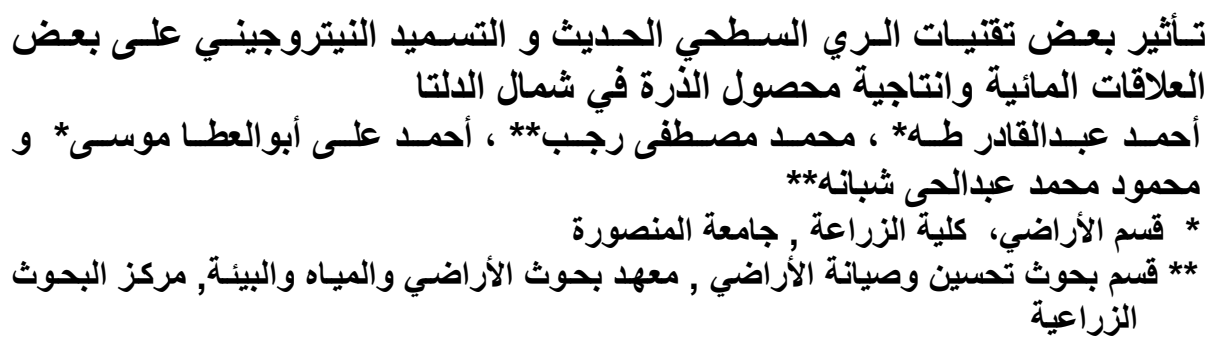

لتقييم بعض تقنيات الري السطحي المحسن و التسميد النيتروجيني على بعض برك العلاقـات

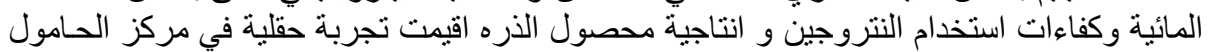
بمحافظة كفر الثيخ في شمال النغال الدلتا. و أهم النتائج المتحصل عليها:-

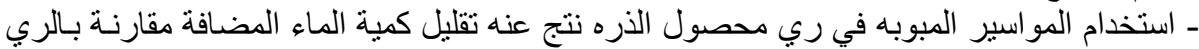

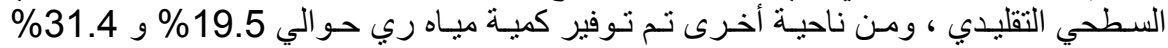

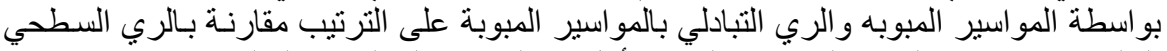

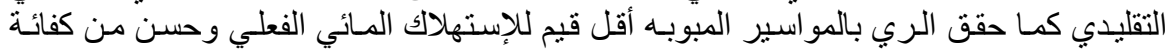

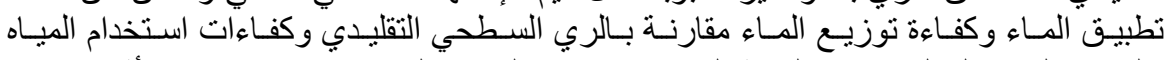

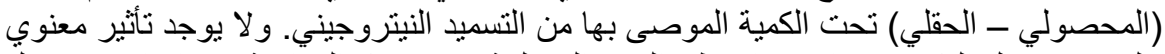

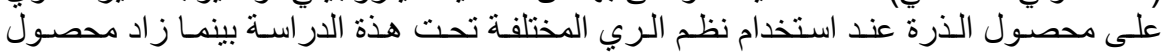

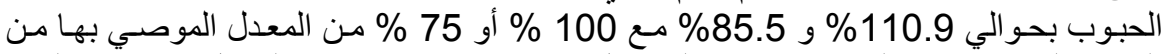

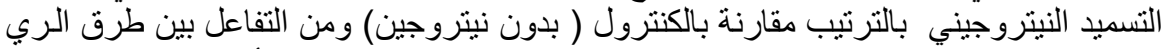

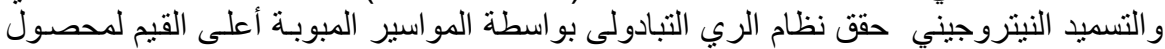
الحبوب و القش وتبعه نظام الري بالمو اسير المبوبة تحت أعلى القيمة من التسميد النبترجيني.

كلية الزراعة - جامعة المنصورة مركز البحوث الزراعية أ.د / السيد محمود فوزي الديدي الديدي أ.د / محمود أحمد عبد الّليم أبو السعود فيود 